\title{
Problemas Rurais Contemporâneos
}

\author{
Eng. agr. Romolo Cavina \\ (Prof. de Economia Rural da Universidade Rural).
}

\begin{abstract}
A
$\mathbf{S}$ questões que hoje se antepõem à agricultura brasileira têm sua origem no sentido da nossa formação e na estrutura que, à nossa economia, fưi imposta por êsse sentido e pela política portuguêsa. Sem um ligeiro preâmbulo histórico não se compreenderá o presente, como sem o estudo da atualidade não se poderão indicar medidas que nos conduzam à solução dêsses problemas.
\end{abstract}

Valiosa é a pesquisa na história pátria, como importante será o estudo, o ccnhecimento local dos inúmeros e interligados problemas que interessam ao mundo rurai de hoje.

Comecemos a nossa análise com um primero item sôbre o uso da terra.

Primeiro - os problemas rurais dizem respeito ao uso da terra, das plantas e dos animais, encarado como profissão ou maneira de ganhar a vida.

A profissão rural é a mais nobre e uma das mais antigas ocupações do homem, talvez por isso mesmo, ainda é um pouco arte e um pouco ofício. Utn agricultor de hoje aprendeu com o agricultor de cntem a experiência profissional que deverá seguir e sabe já ter dado resultado. Isto significa, por outro lado, que o agricultor é essencialmente tradicionalista, conservador e rotineiro, difícil e demcradamente aceitando invocações.

Sabe que uma certa prática deu certo, devendo, portanto, ser repetida. Também disto resulta ser a agricultura, uma atividade de movimentos certos lentos, seguros, pausados.

Segundo - as atividades rurais assumem uma importância tôda especial, medida em poucos números: cêrca de $65 \%$ da população do mundo a elasse dedica. Quantos ao Brasil sabemos que $67 \%$ da população economicamente ativa é rural.

Terceiro - os progressos da ciência como um todo e da Biologia e da Química em particular, tomam vulto e se difundem ràpidamente nas atividades industriais, refletindo poderosamente no comércio. Mas o agricultor dada a sua índole tal como referido no item anterior - sempre demcra mais em aceitar as inovações, ainda que tenham sido descobertas para fins especialmente rurais.

Tomemos o exemplo do DDT, seus derivados e sucedâneos que, comoinseticidas, são aplicados na defesa sanitária das lavouras. A muito custo- 
consegue um fitossanitarist ‘ convencer o agricultor a fazer as aplicações recomendadas. Depois de muita insistência será atendido, com certa desconfiança, mas o crânio de bovino ou a cruz de madeira não sairão de cêrca porque destinadc's a afastar o demônio, as pragas, as doenças.

Êste e muitos outros exemplos pelo mundo afora mostra que a gente rural forma um mundo próprio, que pensa, age, sente de maneira apropriada, características. E' gente que vive uma vida diversa da urbana e a qual os citadincs, sem compreender. menosprezam e ridicularizam, esquecendo que, desde o café da manhã à televisão dela dependem, estando sempre a dever algo ao humilde e honrado trabalhador do campo.

Quarto - o quarto ponto básico é uma primeira aproximaçáo do panorama brasileiro. Para tanto seja-me permitido uma necessária e pequena digressão histórica.

Estamos na Europa, século XVI, em Portugal, pequeno reino á margem do Atlântico, povo de pastores e agricultores, ccrm pouca terra fértil à disposição e ainda recurso modestos para usá-la.

Guerras e invasões agitavam os lusos e a vida era áspera, anda sob o regime feudal. A posição marítima, privilegiada, apontava o comércio e a navegação, despertava a vocação oceânica que seria qualidade de vulto nesse povo e que dificultaria a colonização baseada no uso sistemático das terras que descobriria.

Atirando-se à aventura marítima os portuguêses descobriram o Brasil em 1500. Aqui chegaram dispostos a "levar de volta a Lisboa tudo quanto tivesse valor e pudesse ser carregado", como disse um historiador. Buscavam produtos para seu comércio, ambicionavam encontrar fácil e abundante o ouro e outras preciosidades.

Evidentemente, com tais intenções, com estas características, cs portuguêses não pretendiam esforçar-se na utilização sistemática das terras descobertas. Tal como fizeram no Brasil desde o princípio: eximiam-se do trabalho, guardando para si a posição de empresáric; e os cargos públicos, atribuindo ao escravo, ameríndio e negro, a execução das demais tarefas.

Mas, a atividade econômica não opera isoladamente. Reflete-se e é refletida, numa interação de fatôres, numa extraordinária interdepenđência, nas atividades políticas, nas atitudes sociais, no compcrtamento moral. E o conjunto, sofrendo o impacto da ecologia tropical e da miscigenação, molda o homem e suas instituições. Lá, onde antes não se plantava o trigo nem a uva e nem se criava o boi, onde antes era lugar infenso ao branco civilizado, nasceu uma poderosa nação brasileira, ainda hoje ostentandc marcas recebidas no longínquo século XVI.

Os navegadores portuguêses encontraram uma grande área de terras tropicals habitadas por uma população esparsa e ainda na idade da pedra. Nenhuma possibilidade imediata para o comércio regular e amplo, como na India. Difícil, demorado, oneroso seria instalar aqui uma entidade econômica para resultados valiosos. 
As ameaças da concorrência de outros povos navegadores, a esperança na mineração, animaram os lusos à colonização. Ainda assim, é de 1534 a criação das capitanias hereditárias, cuja extinção se verificou em 1549 com a vinda do primeiro governador-geral.

Donatários e governadores traziam recomendações especiais sôbre os problemas da agricultura. A princípio, porém, só se aproveitaram do extratrvismo, a cata, pura e simples, do que a natureza produzia e oferecia.

Depois do açúcar, cuja procura nos mercados europeus crescia sem medida e do qual os portuguêses fizeram um verdadeiro mcnopólio, seguiram-se o algodão e o tabaco.

O prestígio social e político do senhor de engenho, do chefe da família patriarcal criou forte, rica e poderosa classe rural. Bem mais tarde o primado do café amplia a posição da gente rural.

A vida política e econômica do Brasil tem feição nítidamente agrária que, apesar do ciclo da mineração, caracterizou o progresso da colônia e sustentou o Impéric. Esste foi derrubado quando a Abolição tirou ao empresário agrícola a mão-de-obra escrava.

A estrutura agrária que se firmou no Brasil, entretanto precisava ter um fundo auto-suficiente, dada a distância da metrópole, as dificuldades dos transportes e o progresso da própria população.

$\mathrm{PCr}$ isso as propriedades agrícolas se formaram em economia fechada, verdadeiros núcleos populacionais auto-abastecidos e cujas relações com os centros urbanos eram raras e difíceis. Cada fazenda procurava produzir tudo que necessitava para alimentar, vestir e abrigar sua gente. Iam à cidade comprar apenas nólvora e sal.

Assim surgia a indústria doméstica a qual a Côrte tomava medidas excepcionais para impedir. Esta é uma das razões de nos faltar o artezanato e a tradição profissional, o que prejudica fundamentalmente nosso progresso geral e nossa industrialização. Para avaliar êste fato basta comparar os problemas industriais e os rurais em certas micro-economias do sul do país.

Cumpre notar, todavia, que esta agricultura de subsistência era relegada a plano inferior porque também as naus, que daqui deveriam partir carregadas de produtos brasileiros, vinham cheias de produtos sem os quais a vida do reino seria difícil e acabaria igual à do ameríndio. Muito e de tudo deveriam importar para poder exportar, pois, além de tudo, os barcos não podiam navegar vazios.

Fixađos êstes quatro itens, já poderemos delinear a estrutura agrária brasileira em perícdos:

a) pré-cabraliana ou pré-coloniai;

b) colonial;

c) de independência econômica;

d) contemporâneo; $\mathrm{e}$

e) futuro. 
O período pré-colonial se caracteriza pela agricultura ameríndia. Era predatória, rudimentar; não tinham pròpriamente ferramentas, pois năo ionheciam o ferro.

A fogo limpavam o terreno e nêle as mulheres deixavam as poucas sementes que desejavam reproduzir.

O período colonial nos mostra o branco em ambiente ecológico completamente diverso do originário. O trópico desconhecido, cheio de mistérios, de incógnitas, șituado lá onde se supunha que o homem não poderia viver.

E' claro que o uso da terra deveria seguir um método apropriado, mas, quem o conhecia?

Só o tempo e a asscciação das três diversíssimas culturas poderia criar a técnica desejada; da agricultura portuguêsa, junto à ameríndia e à negra, resultaram a arte e o ofício rural no trópico.

À rotina, à lentidão, que caracterizam o progresso agrícola, junta-se o ínfimo nível técnico dus novos agricultores tropicais. O regime impôsto pela metrópole agravará a situação por que objetiva isolar o Brasil, impedir que êle se torne maior que o pequeno reino europeu, e, ainda mais, seja ambicionado pelos seus conccrrentes.

Caracteriza-se êste período por emprêsas onde um fazendeiro branco e muitos escravos movimentam uma grande unidade produtora.

Era a emprêsa do colono branco dominando o ameríndio e o negro e dirigida com um acentuado cunho mercantil, imediatista, para atender às solicitações do mercado exportador.

Tais emprêsas se organizavam para produzir tabaco, açúcar; mais tarde outras surgiram para explorar ourc e diamantes, com a mesma estrutura. Outras, mais tarde ainda, vieram a explorar algodão, café, porém, visando ao comércio com o exterior.

Foi assim que se estruturou a vida econômica nacional durante três séculcs: XVI - XVII - XVIII.

Começou a mudar pouco antes da vinda de D. João VI, quando realmente se iniciou o período de independência econômica, diferente do de independência política.

Ao impulso da presença do rei luso cresceram também as aspirações dcs brasileiros, já conscientes do seu valor e da sua fôrça econômica.

Com a independência política, no primeiro quartel do século XIX, acelera-se o progresso nacional, livre da pressão da metrópole, e o seu mercado interno já faz sentir sua capacidade.

O sentido da grande lavoura, todavia, se acentua com a ajuda do café. Mas a Abolição refletirá pesadamente sôbre a agricultura, e o golpe é tão profundo que a estrutura política mudou; veio a República.

Uma ccnsequência característica da conjuntura brasileira é a propriedade monocultora trabalhada por escravos. Extinta a servidão manteve-se 
essa estrutura, agora baseada no braçc livre, de liberdade mais teórica que prática. Aqui é substancial a presença do imigrante assalariado, concorrendo para a mudança dêsse panorama.

Uma vez que a terra que se buscava apropriar era abundante e fácil, outro não poderia ter sido o sentido de seu uso. Por isso monocultura, grande propriedade, escravo, serão por muito tempo o fundamento da economia rural brasileira. Elle se repete na pecuária e funciona semelhantemente na mineração.

Depois da Abolição, do Império e da República, entretantc; pouco muda o sentido da economia rural, pois continuamos simples fornecedores do comércio internacional, e, assim sujeitcs às oscilações de sua conjuntura.

Nem mesmo o fator trabalho mudou muito: o trabalhador rural de hoje, embora livre, tem uma situação miserável, talvez até mais precária que a do escravo.

Quando a conjuntura internacional impõe, a eccnomia brasileira improvisa com incrivel rapidez: organiza, investe, movimenta, até o esgotamento da fonte ou do mercado; até a mudança da conjuntura ou a vitória de algum concorrente.

O processo da nossa independência econômica, todavia, ainda está em marcha, está em transformação ativa, apesar de moderna. As duas grandes guerras e os progressos da ciência pouco refletiram na agricultura brasileira no sentido do seu aperfeiçoamento. Bem pouco melhorou o nível técnico do empresário e ainda mantemos, em grande parte, a agricultura separada da pecuária .

Nesta fase moderna, atual, começa, todavia, outro sentido para a agricultura brasileira. Relembremos que, no início dêste trabalho, nos referimos a uma vocação oceânica dos lusos do século XVI. Vejamos agora, onde ela ainda se reflete em pleno século $\mathrm{XX}$.

Numa de suas obras, Caio Prado Júnior distingue duas agriculturas brasileiras: uma grande lavoura de expcrtação e uma lavoura de subsistência. Passados quatro séculos ainda nos comportamos do mesmo modo: cuidamos zelosamente da produção para o mercado externo e quase esquecemos o mercado interno.

E' certo, e continuamos com o autor referido, que entre as duas agriculturas existe um espaço comum, porque produtc's exportados são procurados também pelo mercado interno, e produtos de uso local são também exportados. A linha divisória está na proporção das quantidades levadas ao mercado e no fundamento ou objetivo da produção.

Os reflexos econômicos estão à vista: é a lavoura de exportação que nos fornece divisas. O poder aquisitivo internacional da economia brasileira depende dessa agricultura exportadora: café, algodão, cacau, ccuros e pouco mais. E' em torno dela que gira - na realidade - a política cambial. 
A infra-estrutura da economia brasileira tem base na agricultura e na pecuária, e é à custa destas atividades que o país se mantém, cresce, enriquece e se industrializa.

Tal como na colônia lusa, o Brasil de hoje organiza sua vida interna em função do comércio exportador. Se muito vendemos, se há facilidades de câmbio, também muito compramos e o equilíbrio interno segue essas oscilações e o papel principal cabe à exploração da terra.

Há que perguntar se o andamento da nossa economia depende de crises pròpriamente ditas, $\mathrm{cu}$ é conseqüência de uma economia ou de uma economia em crescimento. Responde-se: ambas as causas e muitas outras mais que foram particularmente a conjuntura brasileira.

Há, ainda, outros fatôres a notar: de 1930 para cá o padrão de vida do brasileiro mudou, embora, em parte, à custa das infláções da moeda, do crédito e dcs salários. Também as populações - por fôrça dessa elevação - além de crescerem urbanizaram-se; conseqüentemente, passaram a consumir mais e variado, como se comprova com o crescimento quantitativo e qualitativo do mercado interno.

Desta premissa cabe deduzir que a dicotomia da agricultura, antes mencionada, tende a fazer crescer aquêle terreno comum de que nos falou Prado Júnior: entre agricultura exportadora e lavoura de subsistência, apesar da distinção clara, há um terreno comum em franco crescimento. Esta é uma das características mais vivas e mais profundas dos problemas rurais contemporâneos.

Outra peculiaridade dos problemas rurais contempcrâneos deve ser vista através do nível de preços. Como se sabe, a desvantagem está para o agricultor que, não alcançando recompensa animadora, não procura novas técnicas, enquanto outras atividades the fazem crescente ccncorrência.

Segundo dados da análise macro-econômica do nosso desenvolvimento no período 1934-1954 (conforme estudos do Bancc Nacional de Desenvolvimento Econômico, da CEPAL e da Fundação Getúlio Vargas), a produção agrícola evoluiu de 100 para 140,7 , enquanto a industrial subiu de 100 para 284,5 .

Ainda fazendo 1939 igual a 100 , cis preços em 1954 foram: nível geral de preços no país, 505,0; produção agrícola no mercado interno, 601,0; e produção agrícola no mercado externo, 938,0.

Problemas atuais do aǵricultor brasileiro - São muitos e graves; apontaremos apenas alguns gerais e mais importantes.

As nossas estatísticas mostram um crescimento acentuado do consumo, enquanto a produção agrícola não aumenta na mesma velocidade.

O rendimento por hectare é, em geral, baixo, tendo oscilado muito pouco. Produzimos pouco por unidade de área e por trabalhador rural. Daí uma produção relativamente mais cara.

Obtida a produção, deverá ser vendida, sendo a segunda ação mais difícil que a primeira. E' que, sendo muitos agricultores a oferecer produtcs a poucos 
compradores, evidentemente os preços baixam quando a produção está sendo oferecida pelo agricultor e se elevam quando o agricultcr não tem mais o que vender, encarecendo o produto a caminho do consumidor, ainda em mãos de intermediários.

Os intermediários têm a seu favor os juros altos do dinheiro, que dificultam os empréstimos; pois ainda somos quase capitalistas em relação à agricultura. Deficiências do serviço bancário, desarticulação dos transportes e monopólio das usinas de beneficiamento colocam o agricultor inteiramente a mercê do intermediário, como está o consumidor, tumbém.

Resultado: no campo, paga-se pouco ao produtor que, ccm êsse pouco, deverá comprar caro o que precisa. Daí the faltaram recursos para aperfeiçoar sua técnica, o que não interessa ao mercado, cuja estrutura atual não é remuneradcra para o produtor.

Em consequiência: nas cidades sobe o custo da vida e no campo não há progresso.

Como corrigir tal situação? A disparidade dos preços no mercado interno - o cruzeiro do agricultor tem valor diferente se êle estiver comprando ou vendendo - é um verdadeiro sacrifício para o agricultor e está exaurindo a economia nacional. Há uma verdadeira perda de substância. Para solucionar o impasse deveremos levar ao agricultor medidas que:

$1^{\circ}$ ) melhorem as práticas agrícolas, através da assistência técnica e financeira aos agricultcres;

2. ) garantam os preços no mercado interno para reduzir a disparidade prejudicial ao agricultor e ao consumidor; e

3. $\left.{ }^{\circ}\right)$ melhorem a estrutura do mercado, tornando mais racional a comercialização dos produtos agrícolas. 